\title{
EFFECT OF DENNETTIA TRIPETELA (MMIMI) SEED INTAKE ON THE IOP OF NORMOTENSIVE EMMETROPIC NIGERIAN IGBOS
}

BY

\author{
*TIMOTHY, C. O. AND OKERE C.O. \\ DEPARTMENT OF OPTOMETRY, \\ ABIA STATE UNIVERSITY, UTURU \\ * Corresponding author
}

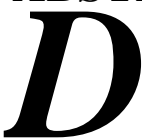

ABSTRACT ennetia Tripetala (mmimi) is a well known forest fruit from the family annonacea and spicy indigenous plant and has been found to contain lots of minerals, vitamins, alkaloids and trace elements which are of medicinal importance. The study was aimed at investigating the effect of DennetIa Tripetala (D. Tripetala) on the intraocular pressure of normotensive emmetropic Igbos of Eastern Nigeria. Forty volunteers (mean age $23.36 \pm 3.60 \mathrm{yrs}$ ) were used for the study. The $10 \mathrm{P}$ of each subject was measured pre and post ingestion of $0.75 \mathrm{~g}$ of $D$. Tripetala seed at 30mins interval for 120 minutes. The findings showed peak reduction of IOP after $60 \mathrm{mins}(11.20 \mathrm{mmHg}$, representing $25.64 \%$ reduction) of consumption and increased towards baseline $(15.6 \mathrm{mmhg})$. Results also showed slight reduction of IOP at the $90 \mathrm{mins}(12.96 \mathrm{mmHg}$ induced value) and $120 \mathrm{mins}(14.40 \mathrm{mmHg}$ induced value) post ingestion. The peak effect of $D$. Tripetala was found to be statistically significant ( $>0.05)$. It is recommended that intake of D.Tripetala seed be encouraged especially among glaucomatous individuals.

KEYWORDS: Dennetia Tripetala, flavonoids, oleoresins, intraocular pressure, glaucomas

\section{INTRODUCTION}

Dennettia Tripetala is a well-known forest fruit and spicy indigenous medicinal plant. It is widely domesticated in the Southern, Eastern and Western part of Nigeria ${ }^{1}$.

Dennettia Tripetala is commonly known as pepper fruit by the English, "mmimi" by the Igbos, "Nkaika" by the Ibibio and Efik, "Imako" by the Urhobo tribe of the Niger-Delta region, and "Igberi" by the Yorubas. It is a common ethnomedicinal plant in West Africa, which appears red when ripe and green in an unripe form with a pungent spicy taste. The parts used include the leaves, fruits, seeds, roots and stem $^{2}$. A survey of existing literatures shows that pepper fruits contain Dennettia essential oils and pheolic acids ${ }^{3}$, ethanol ${ }^{4}$, alkaloids ${ }^{5}$, ethylacetate, flavonoids, tannis and glycosides. Indications show that the rich presence of a type of essential oil called oleoresins determines the aromatic flavouring, colouring and pungent properties of pepper fruits. It also contains a hexanolic constituent (n-hexane) which is toxic to Aedes aegypt larvae ${ }^{3}$. Also it was found out that $80 \%$ of Dennettia oil contains a natural nitro compound called $\beta$-Phenylnitroethane which boosts the insecticidal activity of Dennettia
Tripetala ${ }^{6}$. Vanillin, dennettine (a new 2, 6dimethoxy-chrome), argentinine were isolated along side with uvariopsine from D. Tripetala ${ }^{7}$.

Elemental analysis showed that $D$. Tripetala contains mainly calcium and iron. Others are magnesium, zinc, manganese and copper. Generally, the fruit contains minerals, vitamins, oils, iron flavours ${ }^{8}$, crude proteins, fibre, ash, carbohydrate, sulphur'.

Some of the fruit extracts have been shown to be active as antifungal agents against Sacchromyces Cervisae, Candida Triopicalis, Candida Sp., Crytococeus Sp., Geotrichum Sp., Rhizopus Stolonifer, Aspergillus and Fusarium $S p^{2}$. It can also serve as insecticide against $3^{\text {rd }}$ instar larvae of Aedes aegypt mosquito, bioinsecticides for the control of rice weevil Sitopulus, Zeamais ${ }^{10}$. Medicinally, the leaves and fruits of $D$. Tripetala is used for cough treatment and enhancing appetite. In Igboland, the fruits and seed are sign of hospitality for visitors.

Selah et $a l^{11}$ recorded an epidemiological association between those who have a diet rich in fresh fruits and vegetable and a decreased risk of cardiovascular disease and certain forms of cancer. Intraocular pressure is the pressure within the eyeball as a result of the constant 
formation and drainage of the aqueous humour. It is the internal pressure of which allows the eye to hold on to its shape and function properly. Intraocular pressure is controlled primarily by the rate of secretion or rate of drainage of the aqueous humour. These will be building up pressure leading to increased risk of optic nerve damage, a pathological condition called glaucoma.

Quigley $^{12}$ rated glaucoma as the second leading cause of vision loss worldwide. He also estimated that 66.80 million people are affected by glaucoma worldwide and 6.70 million are bilaterally blind because of the disease. It was said to affect individuals of all age groups but is more prevalent after the fourth decade of life. Black subjects, in comparison with Caucasian subjects are known to have increased risk of optic nerve damage caused by glaucoma ${ }^{13}$. Intraocular pressure is essential in visual health because it sustains the metabolism of the cornea and lens ${ }^{14}$. Generally, the normal range of IOP value is between $13 \mathrm{mmHg}$ to $21 \mathrm{mmHg}$. IOP above these values are considered to be pathological resulting in glaucoma ${ }^{15}$.

Considering the fact that $D$. Tripetala is used among others for therapeutic purposes, its systemic effect may be oblivious. Therefore this work is geared towards determining the effect of Dennettia Tripetala seed on the IOP of normontensive emmetropic Nigerian Igbos.

\section{METHOD}

Forty healthy young volunteers (mean age $23.36 \pm 3.60 \mathrm{yrs}$ ) of Abia State University Uturu were used for the study. These subjects passed the inclusion and exclusion criteria used for the study. After informed consent was sought and obtained from each of them, the pre-test and post-test experimental design was used in this study.

The subjects were selected after a thorough case history, external examination and funduscopy were carried out to ensure good ocular and systemic health. Subjects with ocular and systemic pathologies were not included in the study. Only emmetropic subjects as determined by standard optometric objective and subjective refraction with normal IOP range of $12-21 \mathrm{mmHg}^{15}$ (measured using Schiotz tomometer) were used for study.

Fresh Dennettia Tripetala fruits used for the study were obtained from a local market in Uturu Abia State, after it was authenticated for consumption by a renowned Botanist from Abia State University Uturu.

The fruits of $D$. Tripetala were washed with water and the fruits extracted were dried under the sun. The dried seeds were then weighed out in $0.75 \mathrm{~g}$ (3-5 seeds) and then separated in drug envelopes.

The intraocular pressure pre-ingestion of $D$. Tripetala was measured and recorded as the baseline value. Then $0.75 \mathrm{~g}$ weighed seeds of $\mathrm{D}$. Tripetala was given to the subjects for ingestion ${ }^{4}$. The IOP was measured post-ingestion of the seeds after 30 minutes of ingestion to allow for digestion and assimilation. The IOP was again measured subsequently after 60 minutes, 90 minutes and one 120 minutes.

\section{RESULTS}

Results obtained showed that consumption of $0.75 \mathrm{~g}$ of $D$. Tripetala seed gradually reduced the mean IOP from $15.6 \mathrm{mmHg}$ to $11.20 \mathrm{mmHg}$, (25.64\% reduction) after 60 minutes; and gradually reversed towards baseline value at 120 mins-post ingestion. The mean induced change in IOP at 60 minutes was $4.00 \mathrm{mmHg}$ (table 1). The effect was found to be statistically significant $(\mathrm{p}>0.05)$.

\section{DISCUSSION}

Result obtained from this study showed that ingestion of $0.75 \mathrm{~g}$ of $D$. Tripetala reduced the IOP of normotensive emmetropes though not sustained (table 1). At 30 mins post consumption of pepper fruit, the IOP was reduced by $17.30 \%$ $(12.90 \mathrm{mmHg})$ from the mean baseline of $15.60 \mathrm{mmHg}$. This decrease in IOP was consistent at 60 mins (a $25.64 \%$ reduction $11.20 \mathrm{mmHg}$ ) and then started reverting towards baseline. This decrease was therefore not found to be sustained after 60 minutes post consumption of the seeds. The IOP returned almost to baseline after 120 minutes (a mean of $15.40 \mathrm{mmHg}$ ) post ingestion of $0.75 \mathrm{~g} D$. Tripetala.

There was a statistically significant $(\mathrm{P}<0.05)$ reduction of IOP after 30 minutes and 60 minutes. This reduction in IOP recorded was probably due to the ascorbic acid, magnesium, flavonoid, melatonin, thiamin, vitamin $\mathrm{B}_{12}$, lipoid acid content of D. Tripetala.

Ascorbic acid had been established to support the osmotic influx of water following osmolarity elevation of blood artificially leading to the fall in $\mathrm{IOP}^{16}$. According to Trygre ${ }^{17}, 1.50 \%$ 
of the anterior chamber contents are renewed each minute and the half life of anterior chamber aqueous is some 45 minutes corresponding to a daily production of about $2.80 \mathrm{ml}$. Therefore when $D$. Tripetala is ingested and its constituents absorbed into the intravenous blood stream, the ascorbic acid constituents through the blood stream reaches the eye and lowers the inner eye pressure through increased blood osmolarity.

The presence of Ascorbic acid in the filtration angle via the anterior chamber and iris strengthened the collagen fibres of the meshwork tissues preventing it's shrinkage, narrowing and blockage by pigment cells which normally circulate within the aqueous and drain out via the trabecular meshwork. The increase after 90 minutes and 120 minutes was probably due to the amount of ascorbic acid and magnesium in $0.75 \mathrm{~g}$ Dennettia Tripetala was not enough to continue with the reduction of $10 \mathrm{P}$. Furthermore Gasper $^{18}$ noted that magnesium supplementation improve blood supply to the eye and assisted with vision in glaucomatous patients. Flavonoid, another constituent of $D$. Tripetala is attributed to reduce IOP. Head et al $^{19}$ explained that flavonoids assist with collagen stabilization and synergizes the effect of vitamin C. The effect of flavonoid in IOP reduction is thought to be as a result of the reduction in excessive permeability of blood aqueous membrane within the eye.

The presence of lipoic acid (fatty acid) probably helped in the reduction of IOP by increasing glutathione in red blood cells and lacrimal fluid of glaucomatous patients thereby reducing the intraocular pressure ${ }^{19}$.

Finally, the presence of melatonin, thiamine (vitamin $B_{1}$ ) and vitamin $B_{12}$ perhaps also contributed to the reduction in IOP. This is due to the fact that melatonin levels have been found to decrease in glaucomatous patient and normal diurnal rhythms of IOP fluctuation reflect melatonin rhythms ${ }^{20}$.

Since glaucoma has been found to be one of the leading causes of blindness worldwide the need for cheaper and acceptable adjuvant remedy becomes necessary. Therefore $D$. Tripetala ingestion should be encouraged as an adjuvant in the treatment of glaucoma.

\section{TABLE 1: CHANGES IN INTRAOCULAR PRESSURE DUE TO INGESTION OF 0.75G OF D. Tripetala WITH TIME (MEAN BASELINE IOP $=15.6 \mathrm{mmHg}$ )}

\begin{tabular}{|l|l|l|l|}
\hline $\begin{array}{l}\text { Time } \\
\text { interval (mins) }\end{array}$ & $\begin{array}{l}\text { Mean induced } \\
\text { IOP }\end{array}$ & $\begin{array}{l}\text { Mean induced } \\
\text { Change in IOP }\end{array}$ & $\begin{array}{l}\text { Percentage } \\
\text { mean change \% }\end{array}$ \\
\hline 30 & 12.90 & 2.70 & 17.31 \\
60 & 11.20 & 4.00 & 25.64 \\
90 & 12.96 & 2.64 & 16.92 \\
120 & 14.40 & 0.20 & 1.28 \\
\hline
\end{tabular}

\section{REFERENCES}

1. Chandraseharen, C. (1994): Non-wood forests products - a global view of potentials and challenges. Paper for international seminar on management of Minor Forest produces, Dehra-Dun, India, FOA Rome, 10-5.

2. Ejechi, B. O., Nwafor, O. E. and Okoko F. J. (1999): Growth inhibition of Tomato-rotfungi by phenolic acids and essential oil extracts of pepper fruit. Food Res. Int., 32 (6):395 9.

3. Anyaele, O.O. and Amusan, A.A.S. (2003): Toxicity of Hexanolic extract of $D$. Tripetala on larvae of accedes Aegyptic. Afri. J.
Biomed Res., 6(10): 49-53.

4. Okwu, D.E. and Morah, F.N.I. (2004): Mineral and nutritive value of Dennettia Tripetala fruits. Fruit Paris, 59 (6): 439-42.

5. Rossana, E., Janvier, L., Lara, M., Jose Enrique O' Connor, Magdelena, M., Migriel, C., Edet, M., Ivorra M., Issekutz, C.A., Cortijo J., Morlillo, J.E., Blazquez, M. D. and Sanz Maria Jesus (2003): Effect of two Phenathrene alkaloids on Angiostenin II induced Leukocyte endothelia cell interaction in vivo. Br. J. Pharma., 140:1057 67.

6. Okogun, F. I. and Ekong, D.E.U. (1969): The fragrant principle of fruit of Dennettia 
Tripetala Baker: A new naturally occurring Nitro Compound. Chem. and Indust. Lond., 19724.

7. Janview, Lopez Martin, Edet, M., Herminio, B., Sanz Maria Jesus and Maria A. (2002): Chromone and phenanthrene Alkaloids from Dennettia Tripetala. Chem. and Pharmaceut. Bulletin, 20 (12): 16135.

8. Okafor, J.C. (1980): Edible indigenous woody plants in the Rural Economy of the Nigeria Forest Zone. For. Ecol. Mgt., 3:4555.

9. Udoessian, E. I. and Ifon, E.T. (1984): Chemical studies on the unripe and ripe fruits of Dennettia Tripetala. Food Chem., 13(4): $257-63$

10. Adedire C.O. and Akinkurolere, R.O. (2005): Bioactivity of four plant extracts on coleopterous pest of stored cereals and grain legumes in Nigeria. Zool. Res., 26(3): 23449.

11. Selah, N.N., Paranga, N.J., Tisjihurg, G., Bolwel, G.P., Rice, E. and Evang, C. (1993): Poly-phenolic Radicals as chain breaking Antioxidants. Arch. Bio. Chem. Physics., 2:338-46.

12. Quigley, H. A. (1996): Number of people with glaucoma worldwide. Br J. Ophthalmol., 601: 664-7.
13. Leske, M.C., Connell, A.M., Wu, S.Y., Hyman, L. and Schachat, A.P. (1995): Open angle glaucoma - The Barbados eye study. Arch. Ophthalmol., 115(8): 1057-67.

14. Alder, F.H (1950): Physiology of the eye. $2^{\text {nd }}$ edn. The C.V. Mosby Publishers, St Louis, pp 77.

15. Marcus, D. F., Krapin, T., Podos, S.M. and Becker, B. (1920): The effect of exercise on intraocular pressure in human beings. Invest. Opthalmol., 63: 673-6.

16. Charles, D.M, (1985): Therapy of glaucoma Therapeutics and Pharmacology. $7^{\text {th }}$ edn. The C.V Mosby Company Princeton, pp 167-86.

17. Trygre, S. (2003): Ocular Anatomy and Physiology. Black Science Ltd, pp 41-3.

18. Gasper, A. Z. (1995): The influence of magnesium on visual field and peripheral Vasospasm. Glaucoma Opthalmol., 209: 113.

19. Head, I. and Kathleen, C. (2001): Natural Therapies for Ocular Disorder, part two: Cataract and glaucoma. Alternat. Rev., 6(2) 141-66.

20. Igwe, S. A. and Chukwuka, F.C. (1996): Effect of Ascorbic acid (vitamin C) on intraocular pressure of Normotensive Igbo (Nigerians). JNOA, 7 (1): 21-24. 